\title{
Modern Terörizmin Beşinci Dalgası: Devletlerin Uluslararası Terörist Örgütlerle İş Birliğinin Sebepleri ve Sonuçları
}

915

Güvenlik Stratejileri

Cilt: 16

Sayı: 36

\section{The Fifth Wave of Modern Terrorism: Causes and Possible Consequences of the States' Cooperation with International Terrorist Organizations}

\author{
Rüştü Salim Savaş BİÇER*
}

$\ddot{O} z$

David Rapoport 2004 yllinda yazdiğ makalesinde, uluslararası terör hareketlerinin tarihsel süreç içerisinde dalgalar halindeki gelişimini incelemiş, teorik ve kavramsal olarak terörizmin uluslararası ilişkiler açısından ne anlama geldiğini açıklamıştır. Günümüzde uluslararası terörizmin geldiği noktada yeni bir terörizm dalgası, uluslararası ilişkiler alanının anarşik yapısında devletlerin ulusal çıkarları uğruna terörizmi kullandiğl, terörist örgütler ve gruplarla iş birliğini savaşın farklı bir uygulama biçimi olarak meşrulaştırma gayretine girdiği bir süreci ifade etmektedir. Bu makalede, hibrit savaş yöntemleri ile başlayan, terör örgütlerinin devletler tarafindan ortaklar olarak adlandırılarak açıç̧a desteklendiği hatta silahlandırıldiğı sürecin sebep ve muhtemel sonuçları incelenecektir. Modern terörizmin dört dalgasindan sonra beşinci bir dalga olarak devletlerin ulusal çıkarları uğruna terör örgütleri ve teröristlerle açık olarak iş birliği yapmaları ve terörü genel savaş dışında

\footnotetext{
* Dr. Öğr. Üyesi, Nişantaşı Üniversitesi, İktisadi, İdari ve Sosyal Bilimler Fakültesi, ORCID: 0000-0001-6318-9814, e-posta: savas.bicer@nisantasi.edu.tr.
} 
916

Güvenlik Stratejileri

Cilt: 16

Sayı: 36

bir çatı̧̧ma biçimi olarak uygulamaları, uluslararası terörle mücadelenin uluslararası iş birliği içerisinde sürdürülmesinin karşısındaki en büyük engel olarak karşımıza çıkmaktadır. Daha önce Beşinci Dalga olarak öne sürülen terör hareketlerinin aslında Rapoport'un tanımladiğ ilk dört terör dalgası içerisinde mütalaa edilebileceği, ancak devletlerin terör örgütleri vasıtasıyla ulusal çıkarlarını koruma gayreti içerisine girdiği sürecin gerçek bir yeni terör dalgası olduğu değerlendirilmektedir.

Anahtar Kelimeler: Uluslararası Terör, Terör Örgütleri, Terör Dalgaları, Ulusal Çıkarlar, Uluslararası Güvenlik.

\section{Abstract}

In his article written in 2004, David Rapoport examined the waves of international terrorist movements in the historical process and explained what terrorism means in terms of international relations theoretically and conceptually. Today, at the point where international terrorism has come, a new wave of terrorism represents a process in which states use terrorism for the sake of their national interests in the anarchic structure of the field of international relations, and attempt to legitimize cooperation with terrorist organizations and groups as a different form of war. In this article, the causes and possible consequences of the process in which terrorist organizations are openly supported and even armed by states as partners, starting with hybrid warfare methods will be examined. As a fifth wave after the four waves of modern terrorism, the states' open cooperation with terrorist organizations and terrorists for the sake of their national interests and their application of terrorism as a form of conflict other than general war is the biggest obstacle to the continuation of the fight against international terrorism in international cooperation. It is assessed that terrorist movements, which were previously claimed as the Fifth Wave, can actually be considered within the first four terror waves defined by Rapoport, but the process in which states try to protect their national interests through terrorist organizations is a real new wave of terror.

Keywords: International Terrorism, Terrorist Organizations, Terror Waves, National Interests, International Security. 
Modern Terörizmin Beşinci Dalgası:

Devletlerin Uluslararası Terörist Örgütlerle İş Birliğinin Sebepleri ve Sonuçları?

\section{Giriş}

1970'li yıllarda ortaya çıan dinin terörizme olan etkileri konusundaki ilk çalışmaları yapan akademisyenler konuya tamamen siyasi bir olgu olarak yaklaşmışlar ve dinin terörist şiddetin en hayati bileşeni olduğunu savunmuşlardır. ${ }^{1}$ Onlara göre, aynı zamanda zeki birer siyasetçi olan terörist grup liderleri, dini siyasi amaçları için manipüle etme konusunda her zaman başarılı olmuşlardır. Terörizmin dalgaları konusundaki ilk çalışmalar, özellikle İncil'in siyasi hareketlerin kaynağı olarak ele alınması konusunda başlatılan tartışmaların sonucunda ortaya çıkmış, akabinde antik çağdan günümüze kadar terörizmi inceleyen ve açıklayan bilimsel makaleler yayımlanmıştır. ${ }^{2} \mathrm{Bu}$ konudaki önemli bir üçleme olan; "Terör ve Mesih", 3 "Mesih ve Terör Yaptırımları" ${ }^{4}$ ile "Korkudan Titreme; Üç Dinin Geleneklerinde Terör", dinin motive ettiği terörizm konusundaki çağdaş çalışmalara örnek olarak verilebilir. Her üç araştırma da terörist faaliyetlerin uzun bir süreç içerisinde etkili olabilmek için dinden kaynaklanan azim ve gayrete olan ihtiyaçlarının son derece hayati olduğunu vurgulamaktadır. Bu çalışmalar, çoğunlukla modern bir fenomen olduğuna inanılan terörizmin, bireylerin inançlarına yönelik varoluşsal tehditlere karşı kullandığı ve tarihi çok eskilere dayanan bir yöntem olduğunu ortaya koymaktadır. Burada söz konusu olan inananların kurtuluşa kavuşması, eyleme geçmeyenlerin ise zalimlere zımni destek verenler olarak görülüp cezalandırılmasıdır. ${ }^{6}$ Yani terörist bir faaliyet için asla masum, tarafsız ya da seyirci yoktur.

${ }^{1}$ Bruce Hoffman, Inside Terrorism. New York, 2006, Columbia University Press, s. 40.

${ }^{2}$ David C. Rapoport, "Moses, Charisma, and Covenant," The Western Political Science Quarterly 32, no. 2, Haziran (June) 1979, s. 123-143.

${ }^{3}$ David C. Rapoport, "Terror and the Messiah: An Ancient Experience and Some Modern Parallels." Ed. D. C. Rapoport \& Y. Alexander, The Morality of Terrorism: Religious and Secular Justifications, Columbia University Press, New York 1982. s. 13-42.

${ }^{4}$ David C. Rapoport, "Messianic Sanctions for Terror", Comparative Politics 20, 1988, s. 195-213.

${ }^{5}$ Rapoport, D. C. (1984). "Fear and trembling: Terrorism in three religious traditions", American Political Science Review, 78(3), s. 658-677.

${ }^{6}$ Randall D. Law, The Routledge History of Terrorism, Routledge, New York, 2015. 
Bizden ya da onlardan olanlar vardır. Terörizm çalışmalarının öncülerinin önemle üzerinde durduğu bir diğer tespitleri de farklı zaman, din ve coğrafi bölgelerde görülen terör hareketlerini birbiri ile ilişkilendiren unsurlar olarak kullanılan taktikler, silahlar ve iletişim yöntemleri olduğudur. ${ }^{7}$ Öncü sayılabilecek bu terör incelemeleri, terörizmin aslında karakteristik özelliğinin dairesel olduğundan hareket eden "Dalga Teorisi" için bir temel çalışma ve çıkış noktası olmuştur. Bu konudaki temel kaynaklardan olan ve Amerika Birleşik Devletleri'nde (ABD) gerçekleşen 11 Eylül terör saldırıları sonrasında yayınlanan David Rapoport'un “Asi Terörün Dört Dalgası ve 11 Eylül” isimli çalışmasında, terörün modern kültüre nasıl derinden yerleștiğini anlatabilmek amacıyla, başkaldııı ya da isyan kapsamındaki terörizm anlatılmaktadır. ${ }^{8}$

\section{Terör Çalışmaları, Terör Tanımları ve Terörizm Dalgaları Kavramı}

$\mathrm{Bu}$ aşamada, "Asi ya da İsyancı Terör" tanımının kısa bir açıklamasını yapmakta yarar bulunmaktadır. Klişe olarak, özgürlük savaşçıs1 ve teröristin kim olduğu durulan ve bakılan tarafa göre değişiklik göstermektedir. Sadece kişi, kurum, örgüt yada devletlerin değil, terör çalışan akademisyen ve yazarların da farklı bakış açıları, özellikle iç savaş ve ayrılıkçı terör söz konusu olduğunda daha da belirginleşmektedir. ${ }^{9}$ Tartışmalı bir genel terör ifadesini kullanmak yerine, daraltılmış şekliyle sadece isyancı terör ifadesini kullanmak suretiyle, terörist isyancı grupları, daha geniş bir kitleyi etkilemek için kamusal sivil hedeflere karşı sistematik bir ayrım gözetmeyen şiddet eylemleri uygulayanlar olarak tanımlayıp, bu tür şiddetin nihai amacını, hükümeti, açıkça yenilgiyi kabul etmek de dâhil olmak üzere siyasi tavizler vermeye zorlamak olarak açıklamak mümkündür. Bu tanımı

${ }^{7}$ Rapoport, 1984, s. 659.

${ }^{8}$ David C. Rapoport, "The Four Waves of Rebel Terror and September 11", Anthropoetics, 8(1), 2002.

9 Gordon H. McCormick, "Terrorist Decision Making", Annual Review of Political Science 6, 2003, s. 473. 
Modern Terörizmin Beşinci Dalgası:

Devletlerin Uluslararası Terörist Örgütlerle İş Birliğinin Sebepleri ve Sonuçları?

kullananlar, böylece, isyancı gruplar arasında ayrımlara izin vermekte ve terörizmle ile ilişkili olarak görülen diğer değişkenleri tanıma dâhil etmemektedirler. ${ }^{10}$ Terörizm çalışan akademisyenlerden birçoğuna göre terörizmin tanımlayıcı bir özelliği kasıtlı olarak sivillere saldırmasıdır. ${ }^{11}$ $\mathrm{Bu}$ özellik, terörizmi askerî hedeflere yönelik "normal" isyancı saldırılardan ayırmaktadır. ${ }^{12}$ Sivillere yönelik şiddet, terörist isyancı grupları diğerlerinden ayırmak için kendi başına çok geniş bir kriterdir ve "terörizm" deyince çoğu insanın aklına ilk gelen karşı tarafla iş birliğini cezalandırmak veya caydırmak için sivillere karşı şiddet uygulamak değildir. Neredeyse bütün isyancı gruplar ve iç savaşlarda yer alan bütün taraflar, sivilleri karşı tarafa yardım sağlamaktan caydırmak ve kendileri ile iş birliğine zorlamak için bir "kontrol" biçimi olarak bireyleri hedef alır, kısacası sivil hedeflere saldırı çok sık kullanılan bir yöntemdir. ${ }^{13}$ Tanımı kasıtlı olarak ayrım gözetmeyen şiddete daraltarak, bu daha yaygın şiddet biçimini dışlamak ve terörizmi en fazla korkutucu kılana odaklanmak, onun rastlantısallığ 1 dışında masum sivillerin kasıtlı olarak hedef alınması gibi hiçbir mazeretin arkasına sığınmayı mümkün kılmayan eylemlerini terör genel tanımı dışında ama amacı içerisinde ele almakla mümkün olabilecektir. Bu çalışmada, incelenen teorik çalışmaların gereği olarak, isyancı terör ifadesi kullanılmakta, 11 Eylül 2001 terör tarihinin en yıkıcı sonuçlara sebep olan günü olarak değerlendirilmektedir. Sadece saldırının bizzat kendisi değil, yarattığı sonuçlar ve ilan edilen "savaşın" günümüze kadar uzanan etkileri, uluslararası düzenin yeniden şekillenmesinde büyük ölçüde rol oynamıştır. ${ }^{14}$ Öncelikle inceleyeceğimiz modern terörün dört

\footnotetext{
${ }^{10}$ Virginia Page Fortna, "Do Terrorists Win? Rebels' Use of Terrorism and Civil War Outcomes", International Organization, Summer 2015, Vol. 69, No. 3, s. 522.

${ }^{11}$ Bruce Hoffman, Inside Terrorism, Columbia University Press, New York 2006, s. 40.

12 Audrey K. Cronin, "Behind the Curve: Globalization and International Terrorism", International Security 27 (3), s..32-33.

${ }^{13}$ Andrew H. Kydd ve Barbara F. Walter, "The Strategies of Terrorism", International Security 31(1), 2006, s. 66-69.

${ }^{14}$ Rapoport, 2002, s. 50-52.
}

\section{9}

Güvenlik Stratejileri

Cilt: 16

Say1: 36 
dalgasını tetikleyen olayları göz önünde bulundurduğumuzda, yeni bir tür terör dalgası ile karşı karşıya olduğumuz dikkate değer bir analizdir.

Güvenlik Stratejileri

Cilt: 16

Sayı: 36

\section{Modern Terörün Dört Dalgası}

Modern Terörün Dört Dalgası, kırk yıllık bir süreç içerisinde gerçekleşen bir döngüyü dalga olarak tanımlamaktadır. Bu dönemde bir dalga içerisinde yer alan terörist gruplar, diğer ülkelerdeki çağdaşları olan farklı bütün terörist grupların eylemlerinin farkında oldukları gibi, hemen hemen bütün terör örgütleri, iletişim metotları, silahlar ve lojistik kaynak ve yöntemleri dâhil ortak bir teknolojiyi kullanmaktadırlar. En önemlisi ise, dünyanın karşı karşıya bulunduğu bütün olumsuzlukları devrimci bir geleceğin tohumları olarak algılayan bir vizyonu paylaşmaktadırlar. ${ }^{15}$ Rapoport'un işaret ettiği dört terörist dalganın her birisinin kendisine özgü tetikleyici ya da eylem sürecini hızlandırıcı olayları ve imza niteliğindeki taktikleri ile silahları bulunmakta, yine bir sonraki terör dalgasının ortaya çıkmasına sebep olan kaçınılmaz bir kademeli düşüş dönemi görülmektedir. Bir önceki dalgaya ait belirgin özelliklerden bazıları kendisini bir sonraki dalgaya uyum gösterecek şekilde dönüştürmekle birlikte, genel anlamıyla bir sonraki dalgaya geçiş bir öncekinin ortadan kalkması olarak kabul edilmekte ve değerlendirilmektedir. Bu birbirini izleyen dört dalga; Anarşist Dalga (1878-1919), Sömürgecilik Karşı1tı Dalga (1920-1960), Yeni Sol ya da Marksist Dalga (1960-1990) ve Dini Dalga ya da Köktendinci Dalga (1979- günümüze) olarak ifade edilmektedir. ${ }^{16}$

Anarşist Dalga, 1878 yılının 24 Ocak günü az bilinen bir anarşist figür olan Vera Zasulich'in St. Petersburg'da bir polis şefini vurup

15 Jeffrey Kaplan, "Waves of Political Terrorism”, Summary and Keywords Waves of Political Terrorism, Oxford Research Encyclopedia of Politics, 2016, s. 4, https://www.researchgate.net/publication/319910997_Waves_of_Political_Terrorism_ Summary_and_Keywords_Waves_of_Political_Terrorism_Oxford_Research_Encyclo pedia_of_Politics, (Erişim tarihi; 05 Eylül 2020).

${ }^{16}$ David C. Rapoport, "The Four Waves of Modern Terrorism." Attacking Terrorism: Elements of a Grand Strategy, Ed. Audrey Kurth Cronin ve James M. Ludes, Georgetown University Press, Washington DC, 2004, s. 47. 
Modern Terörizmin Beşinci Dalgası:

Devletlerin Uluslararası Terörist Örgütlerle İş Birliğinin Sebepleri ve Sonuçları?

yaralaması ile başlayıp yayılmıştır. Saldırıya uğrayan kişinin siyasi tutuklu ve mahkûmlara kötü muamelede bulunan bir devlet görevlisi olduğunun duruşmalarda ortaya çıkması ve Zasulich'in mahkemede verdiği "Ben bir katil değil, teröristim" ifadesi unutulmaz bir an olarak tarihe geçmiştir. ${ }^{17}$ Böylece terör dalgasının propaganda gücünün kullanıldığı ve etkili olduğuna tanıklık edilen bir dönem başlamıştır. ${ }^{18}$ Rusya'da ortaya çıkan bu dalga kısa sürede Batı Avrupa, ABD ve hatta Japonya ile bugün de hatırlanan 4 Mayıs gösterilerine sahne olan Çin dâhil olmak üzere bütün dünyaya yayılmıştır. ${ }^{19}$ Anarşist Dalga'nın ilk yılları, yani 1880 ile 1890 yılları arasındaki, "Suikastlerin Altın Çağı" olarak bilinen, devlet yöneticileri, üst düzey siyasetçiler, asker ve polislerin anarşistler tarafindan öldürüldüğü bir dönemdir ${ }^{20} \mathrm{Bu}$ dönemde suikastlerde genel olarak kullanılan silah ve patlayıcıların çok belirgin ve karakteristik farklılıkları yoktur. Eski dönem terör eylemlerinden farklı olarak, uluslararası iletişim teknolojilerindeki gelişme sonucunda, Rusya'daki anarşistlerin devrimci fikir ve öğretilerini bütün dünyaya yayabilmeleri mümkün hale gelmiştir. ${ }^{21}$ Böylece modern çağın terörizmi uluslararası bir kimlik kazanmış, oluşan küresel terör ortamı, sonraki terör dalgalarının da belirleyicisi olmuştur.

Sömürge Karşıtı Dalga öncesinde Anarşist Terör dalgası Birinci Dünya Savaşının başlaması ile birlikte sona ermiştir. İlk büyük savaş, savaşan ülkelerin ulusça tamamının içerisinde yer aldığı bir çatışmanın ilk örneğidir. ${ }^{22}$ Böyle büyük çaplı bir savaşın içerisinde anarşizm

\footnotetext{
${ }^{17}$ Cf. Marc Sageman, Leaderless Jihad: Terror Networks in the Twenty-First Century, Philadelphia University of Pennsylvania Press, 2008, s. 34.

18 Alex P. Schmid, The Routledge Handbook of Terrorism Research, New York: Routledge, 2011 s. 677.

${ }^{19}$ Robert A. Scalapino ve George T. Yu, The Chinese Anarchist Movement, Berkeley: Center for Chinese Studies, Institute of International Studies, University of California 1961.

${ }^{20}$ David C. Rapoport, "The Four Waves of Modern Terror: International Dimensions and Consequences", An International History Of Terrorism: Western And Non-Western Experiences, Ed. J. M. Hanhimäki ve B. Blumenau, Routledge, London 2013, s. 52.

${ }^{21}$ A.g.e. $52-53$.

${ }^{22}$ Bernard Brodie, War and Politics, Macmillan, New York 1973.
}

\section{1}

Güvenlik Stratejileri

Cilt: 16

Say1: 36 
ortadan kalkmış ve çatışmalar ve düşmanlıklar bittiğinde, özellikle Balkanlar başta olmak üzere, Avrupa'daki etnik topluluklar ve

Güvenlik Stratejileri

Cilt: 16

Sayı: 36 Avrupa'nın sömürgeleri, siyasi bağımsızlığın ulaşılabilir olduğunu hissetmeye başlamışlardır. ${ }^{23}$ Amerikan başkanı Wilson tarafından da desteklenen ve cesaretlenen bu talep ve beklentiler, savaş sonucunda imzalanan Versay Antlaşması ile bir hayal kırıklığına dönüşmüştür. ${ }^{24}$ Antlaşma Avrupa'y1 Avusturya-Macaristan İmparatorluğunun parçalanması ile oluşturulan ulus devletlere dönüştürürken, sömürgelerin kendi geleceklerini tayini konusunda alınacak kararlar zamana yayılacak şekilde bu bölgelerde Manda yönetimleri kurulması öngörülmüştür. $\mathrm{Bu}$ bölgelerin, her ne kadar kalıcı olması belirlenmediyse de, sömürge kontrolünün devamı olacakları anlaşılmış ve böylece ikinci dalga tetiklenmiştir. ${ }^{25}$ İrlanda Cumhuriyet Ordusu (IRA) ilk kurulan ulusal kurtuluşçu terör hareketi olmakla birlikte, amaçlarına ulaşmada başarısız olması nedeniyle bu dalgadaki terör guruplarından daha uzun süre faaliyete devam etmiştir. ${ }^{26}$ İkinci Dalga'nın tam anlamıyla harekete geçmesi, Versay Barış antlaşmasından yaklaşık çeyrek yüzyıl sonra gerçekleşmiştir. Rapoport'a göre bu gecikmenin iki ana sebebi bulunmaktadir. Bunlardan ilki Manda rejimlerini tamamen sona erdiren 2nci Dünya Savaşı, diğeri ise uluslararası siyasi sahnedeki üstünlügü kabul edilmiş olan Amerika Birleşik Devletleri'nin sömürgecilik karşıtı siyasetine karşı gösterilen direncin ortadan kalmasıdır. Artık Afrikalı, Asyalı ve Orta Doğulu halkların kendi kaderini tayin hakkı mümkün olabilecektir. ${ }^{27}$ Terörist ile özgürlük savaşçısının karşılaştırma ya da benzer kullanımı, ikinci dalga döneminde gündeme gelmiştir. Aslında en basit haliyle, terörist taktikler kullanan herkes, ne kadar takdir

${ }^{23}$ Krzysztof A. Makowski ve Frank Hadler, Approaches to Slavic Unity: Austro-Slavism, Pan-Slavism, Neo-Slavism, and Solidarity Among the Slavs Today, Poznan 2013, s. 131-152.

${ }^{24}$ John Milton Cooper, Woodrow Wilson: A Biography, Knopf Doubleday Publishing Group, New York 2009, s. 272.

${ }^{25}$ Rapoport, 2013, s. 52-53.

${ }^{26}$ Benedetta Berti, Armed Political Organizations: From Conflict to Integration, Baltimore Johns Hopkins University Press, 2013.

${ }^{27}$ Rapoport, 2013, s. 53. 
Modern Terörizmin Beşinci Dalgası:

Devletlerin Uluslararası Terörist Örgütlerle İş Birliğinin Sebepleri ve Sonuçları?

edilecek amaçları olursa olsun, teröristtir. Filistin'de İngiliz Manda rejiminden kurtulup bir Yahudi devletinin kuruluşu için mücadele eden ve kendilerini özgürlük savaşçısı olarak tanımlayan Irgun örgütü mensuplarının, 1946 yılında King David Otelini bombalamaları tam anlamıla bir terör eylemidir. ${ }^{28} \mathrm{Bu}$ örgütün eylem sırasındaki lideri daha sonra İsrail Başbakanı olan Menahim Begin, 1978 yılında, uzun süre yine terör örgütü olarak kabul edilen Filistin Kurtuluş Örgütü Lideri Yaser Arafat ile birlikte Nobel Barış Ödülünü almıştır. Kendilerini "hükümet terörü" ne karşı ölümüne bir mücadeleye kilitlenmiş özgürlük savaşçıları olarak tanımlayan Yahudi Irgun örgütü mensupları, terörizmin bağımsız bir şekilde analiz edilmesi gerektiğini savunmuşlar ve belirli koşullar altında tek başına terörizmin, nadiren de olsa başarılı olabileceğini göstermiştir. ${ }^{29}$ Aynı konuda diğer bir bilinen görüş ise, eylemin terör eylemi olarak kabul edilmemesi için, demokratik bir ülkede ve muhalefetin barışçı yapıdaki bütün faaliyetlerine izin verilmiş olmasının gerektiği yönündedir. Bu görüşe göre IRA ${ }^{30}$, Kuzey İrlanda'da çöp kutusuna bomba yerleştirdiğinde demokratik çözüm için bir seçenek mevcut olduğundan bu eylem terörist bir hareket ve IRA da terörist bir hareket oluyorken, ANC, ${ }^{31}$ Güney Afrika'da aynı şeyi yaptığında siyasi bir muhalefete ülkede izin verilmediği için terörist bir eylem olmamaktadır. Aynı şekilde ETA $^{32}$ da turistleri öldüren bombalama eylemini Devlet Başkanı General Franko'nun diktatörlük rejimi zamanında yaptığında bu eylem terörist bir hareket olmazken, İspanya'da demokratik hükümet zamanında yaptığında terör eylemi olarak kabul

\footnotetext{
28 Thurstone Clarke, By blood and Fire: The Attack on the King David Hotel, Hutchinson, London 1981, s. 145-147.

${ }^{29}$ Rapoport, 2013, s. 54.

30 IRA; Kuzey Irlanda'nın Birleşik Krallık'tan bağımsızlığını hedefleyen ayrılıkçı örgüt. Açılımı; "Irish Republican Army-İrlanda Cumhuriyet Ordusu".

${ }^{31}$ ANC; Güney Afrika Cumhuriyeti'nde siyahların hakları için mücadele eden örgüt. Açılımı; "African National Congress-Afrika Ulusal Kongresi”.

32 ETA; Bask dilini konuşan toplulukların bağımsızlığını savunan ayrılıkçı örgüt, Açılımı; "Euskadi Ta Askatasuna-Bask Yurdu ve Özgürlük".
}

\section{3}

Güvenlik Stratejileri

Cilt: 16

Say1: 36 
edilmemektedir. Bu görüş oldukça tartışmalı ve iddialıdır. ${ }^{33}$ Yine de Nelson Mandela'nın ANC lideri olarak terörist suçlaması ile yargılanıp

Güvenlik Stratejileri

Cilt: 16

Sayı: 36 hüküm giymesinden sonra, Devlet Başkanı olarak 1993'de Nobel Barış Ödülünü almış olması yine terörizmin başarılı olması durumunun örneği olarak değerlendirilecektir.

Terörist ifadesi 1940'lı yıllarda artık ilk dalgaya göre daha fazla olumsuz çağrışım yaratmış ve bu kapsamda kamuoyu desteğini sağlamakta da başarısız olmuştur. Bunda Yahudi örgütlerce gerçekleştirilen terör eylemlerinin büyük etkisi olduğu söylenebilecektir. Aynı zamanda kanlı eylemlerine rağmen Yahudilere yaranmak isteyen basın organlarının da desteklediği özgürlük savaşçısı etiketi, yeni sol dalga hareketinin başlamasına çok önemli bir katkı sağlamıştır. ${ }^{34}$ İkinci terör dalgası birçok ilkin de yaşandığı bir dönem olmuştur. Diaspora desteğinin ne kadar hayati olduğu ve yabancı devletlerin teröristlere yardım önerilerinin başlaması, ilk defa anarşist terör dalgasında görülmüştür. Yine ikinci dalgada gerilla taktikleri terör eylemlerinde artan bir önem kazanmaya başlamış ve polis güçleri teröristlerin esas hedefi haline gelmiştir. Anarşistlerin terör eylemlerinin süreç içerisinde kentsel alanlardan Maoist fikirlerin artan önemi nedeniyle kırsal alanlara yönelmesi ve köylü nüfusun bu bağlamda öneminin artmas1 dışında, ikinci terör dalgasında dikkat çeken bir özellik olarak birinci dalgadaki devrimci coşkunun yerini daha çok sömürge düzenine karşı yürütülen yerel mücadelelerin alması görülebilecektir. ${ }^{35}$ İkinci terör dalgası 1960'lı yılların ortalarına gelindiğinde tamamen kaybolmuş, ulusal özgürlük mücadeleleri büyük ölçüde başarıya ulaşmış ve ikinci dalga terör hareketlerine artık gerek kalmamıştır. Kuzey İrlanda ve

${ }^{33}$ R.S. Savaş Biçer, "Uluslararası Çatışmaların Değişen Yapısında Terörün Yeri ve Önemi Üzerine Bir İnceleme”, Savunma Bilimleri Dergisi, Kasım 2019, Cilt 18/2, Say1 36, s. 119-120.

34 Bruce Hoffman, Al Qaeda, Trends in Terrorism, and Future Potentialities: An Assessment, Santa Monica, Rand Corporation, California 2003, s.16, https://www.rand.org/ pubs/papers/P8078.html, (Erişim tarihi; 12 Eylül 2020)

${ }^{35}$ Rapoport, 2013, s. 54-56. 
Modern Terörizmin Beşinci Dalgası:

Devletlerin Uluslararası Terörist Örgütlerle İş Birliğinin Sebepleri ve Sonuçları?

İspanya'nın Bask bölgesi gibi bağımsız devlet olmayı başaramayan ya da siyasi değişimin sağlanamadığı birkaç bölgede, IRA ve ETA örgütleri, üçüncü terör dalgası olan Yeni Sol dalgaların gereklerine oldukça iyi uyum sağlamış ve hem hayatta kalabilmek hem de gelişebilmek amacıyla terör eylemlerini siyasi hedefleri ile birleştirmeyi bir yöntem olarak benimsemiştir.

Vietnam Savaşına bir yanıt olarak 1960'ların ortalarında başlayan Yeni Sol terör dalgası, iletişim teknolojilerindeki devrim niteliğinde gelişmelerle birlikte artan savaş karşıtlığının ABD'ye muhalif ülkeler tarafindan da desteklenmesi sonucunda, küresel anti-Amerikancılığın etkisi ile kısa sürede yayılma göstermiştir. Soğuk Savaş yıllarının başlangıcında, Sovyet Rusya'nın barış söylemini ön plana çıkaran, aynı zamanda ABD'yi bir savaş çığırtkanı olarak gösteren politikaları başarıya ulaşmış, Asya, Avrupa ve Orta Doğudaki terörist gruplara yaptı̆̆ lojistik

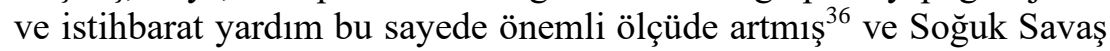
bağlamında devletlerin terörizme verdiği destek kaçınılmaz bir hal almıştır. ${ }^{37}$ Haberleşme teknolojilerindeki hızlı gelişmeler ise, üçüncü dalga terör eylemlerine önceki dalgalara kıyasla daha fazla uluslararası nitelik kazandırmıştır. Üçüncü dalga Yeni Sol hareketin bir önemli özelliği de 1960'lı yılların gençliği için nostaljik anlamı olmasıdır. Romantik sol söylemler, sembol niteliğindeki devrimci liderlerin posterleri ve şarkı sözleri döneme damgasını vurmuş, bugün anladığımız anlamıyla küreselleşme Soğuk Savaş sonrasında ortaya çıkacak olmasına rağmen, modern terörizmin üçüncü dalgası bu sayede bütün dünyaya ulaşmıştır. ${ }^{38}$ Kitlesel zayiatın hedef alındığı olaylar yerine, medyayı yoğun kullanan teröristler için iyi bir televizyon programına haber olmak önde gelen bir eylem hedefi olmuştur. Uçak kaçırma

\footnotetext{
${ }^{36}$ Richard. H. Shultz ve Roy Godson, Dezinformatsia: Active measures in Soviet strategy, Pergamon-Brassey's Washington, DC, 1984.

${ }^{37}$ Claire Sterling, The Terror Network: The Secret War of International Terrorism, Holt, Rinehart, and Winston, New York 1981, s. 140-145.

${ }^{38}$ Sabrina Petra Ramet, Rocking the State: Rock Music and Politics in Eastern Europe and Russia, Westview, Colorado Boulder, 1994, s. 90-91.
}

\section{5}

Güvenlik Stratejileri

Cilt: 16

Say1: 36 
eylemleri, üçüncü dalga teröristlerinin en s1k kullandığ yöntemlerden

Güvenlik Stratejileri

Cilt: 16

Sayı: 36 olmuştur $^{39}$ Şiddet eylemlerini en yoğun kullanan terörist grupların üniversite kampüslerinde üniversite mensupları ya da dağ köylerinde köylüler tarafindan güvenlik güçlerinden saklanması bu terör dalgasının kamuoyuna medya vasıtası ile ulaşmada ve etkilemedeki başarısının göstergesi olarak kabul edilebilir. ${ }^{40}$ Yine anarşist dalga döneminde adam kaçırma ve suikastler de terör örgütlerinin sıklıkla kullandığ 1 eylem türleri olmaya devam etmiştir. ${ }^{41}$

$\mathrm{Bu}$ dalganın bir önceki ikinci dalgadan devraldığı önemli bir terör gerekçesi de milliyetçiliktir. Filistin Kurtuluş Örgütü, sahip olduğu milliyetçi ideolojisiyle, ikinci terör dalgasının özelliklerini bünyesinde barındırmakla birlikte, sosyalist fikirler benimseyen, enternasyonel bir hareket olarak dünyanın çeşitli ülkelerinin terör örgütü mensuplarına eğitim veren ve kendi başına harekete edebilen birçok grubu bünyesinde barındıran özellikleriyle üçüncü dalga içerisinde sayılmaktadır. $\mathrm{Bu}$ özelliklerine ABD'deki 11 Eylül terör saldırıları sonrasında Hamas örgütüne karşı aldığ1 Batı yanlısı tavırla bir yenisini eklemiştir. ${ }^{42}$ Filistin Kurtuluş Örgütünün teorik olarak, milliyetçi ama sosyalist, gerektiğinde Batılı politikaları benimseyen ama aynı zamanda emperyalizm karşıtı olmasının bir benzerini de PKK terör örgütünün ırkçı ama sosyalist, anti-emperyalist; ancak ABD'nin müttefiki olma siyasetinde görmekteyiz. İkinci terör dalgasından üçüncü terör dalgasına yani anarşist dalgaya kalan örgüt ve grupların başarısızlıklarını yeni arayışlarla ve temel değerlerinde değişimle aşma gayretleri, çıkarları ve hedefleri doğrultusunda mücadele çizgilerinde farklı arayışlara girmeleri müteakip terör dalgalarında tekrar karşımıza çıkmaktadır. ${ }^{43}$

\footnotetext{
${ }^{39}$ Rapoport, 2004, s. 57.

${ }^{40}$ Kaplan, s. 7.

${ }^{41}$ Rapoport, 2013, s. 57.

${ }^{42}$ Rashid Khalidi, Palestinian Identity: The Construction of Modern National Consciousness, Columbia University Press, New York 2010, s. 38-40.

${ }^{43}$ Biçer, age, s. 116.
} 
Modern Terörizmin Beşinci Dalgası:

Devletlerin Uluslararası Terörist Örgütlerle İş Birliğinin Sebepleri ve Sonuçları?

Üçüncü terör dalgasının önemli bir sonucu da Vietnam harbi sonrasında Asya'dan Amerika, Avrupa ve Sovyetler Birliğine başlayan mülteci hareketlerinin yarattığ 1 sosyal sorunlardır. ${ }^{44}$ Yeni gelenlerin kültür farklılıkları sonucunda toplumlarda oluşan genel memnuniyetsizlik, birleştirici olması gereken din ögesinin bu kapsamda ayrıştırıcı olarak ön plana çıkması, bütün dünyada farklı biçimlerde ve bölgelerde yeni çatışma ortamları yaratmıştır. Özellikle Orta Doğu'da Arap milliyetçiliğinin İsrail-Arap savaşlarında uğradığı ağır yenilgi, bölgede yaşayan Müslümanların dine daha fazla sarılması ve siyasi İslamcı akımların yükselmesi ile sonuçlanmış, bu dönemde başlayan çatışmalar bir nesil içerisinde üçüncü dalganın kaybolarak modern terörün dördüncü dalgasının ortaya çıkmasının tetikleyicisi olmuştur. ${ }^{45}$

Modern terörün dördüncü dalgası olan din kaynaklı terör ya da köktendinci terör eylemlerinin en kanlı ve ölümcül olanları dünyanın pek çok bölgesinde farklı terör örgütleri tarafindan gerçekleştirilmiş olmakla birlikte, ${ }^{46}$ modern terörün dört dalgası fikrinin yaratıcısı olan Rapoport tarafindan İslam bu dalganın merkezine oturtulmuştur. ${ }^{47} \mathrm{Bu}$ değerlendirmede 1979 İran İslam Devrimi'nin büyük etkisi olduğu bir gerçektir. Ancak, Afganistan'da mücahitlerin din motifli direnişlerinin başarıya ulaşmasını ve Rus işgaline karşı başlayan direniş hareketinin radikal dinci Taliban terör örgütüne dönüşmesini, ayrıca bu motivasyonun sonucunda büyük güçlerin inançla yenilebileceği fikrinin 11 Eylül terör saldırılarına giden yolda El-Kaide terör örgütünün eylem ve düşüncelerine nasıl hâkim olduğunu da Rapoport'un çalışmasına büyük ölçüde etki eden olaylar olarak değerlendirmek uygun olacaktır. ${ }^{48}$ Dördüncü Dalga

\footnotetext{
44 Jeffrey Kaplan, Beyond the Mainstream: The Emergence of Religious Pluralism in Finland, Estonia, and Russia, SKS, Helsinki 2000, s. 20-25.

45 James P. Jankowski, Nasser's Egypt, Arab Nationalism, and the United Arab Republic, Lynne Rienner Publishers, Colorado Boulder 2001, s. 220-222.

${ }^{46}$ Kaplan, 2016, s. 9.

${ }^{47}$ Rapoport, 2013, s. 61.

48 John Miller, Greetings, America. My name Osama bin Laden, Frontline, 1999, https://www.esquire.com/news-politics/a1813/osama-bin-laden-interview/, (Erişim tarihi: 10 Eylül 2020)
}

\section{7}

Güvenlik Stratejileri

Cilt: 16

Say1: 36 
1979 yılında başlamış ve Rapoport'un 40 yıllık döngü teorisini aşacak şekilde halen zirveye ulaştığ konusunda bir emare vermemiş, aksine DÂIŞ'in kurulması ile yeni bir boyut kazanmıştır. ${ }^{49}$

\section{Modern Terörün Beşinci Dalgasına Önermeler}

Sosyal bilimlerde teori bir konunun bütününü kapsayamaz. Bu nedenle dalga teorisi de bu alanda geniş kabul gören faydalı bir tarihi model olmakla birlikte, geliştirilmesi için üzerinde çalışılması gerekmektedir. Bu kapsamda ilk dört dalganın ötesinde, modern terörün beşinci bir dalgasının da var olduğu konusunda araştırmalar yapılmaktadır. Araştırmanın bu bölümünde, Rapoport'un ilk dört terör dalgasını tanıttıktan sonra, beşinci dalga olarak değerlendirilen eylem ve oluşumları da incelemek uygun olacaktır.

Rapoport'a göre, bir dalganın enerjisi, yeni terör gruplarının kurulması için yeterli olmamaya başladığında, terör dalgası da kendiliğinden kaybolmaya başlayacaktır. Burada istisnai durumlar söz konusu olabilmekte, bazı güçlü terör grupları bu süreçten etkilenmeyerek dalganın yaşam döngüsünü sürdürmektedir. El Kaide örgütü gibi bazı radikal İslamcı gruplar, dördüncü dini dalga sırasında, kendilerinden sonra ortaya çıkan seleflerinden daha uzun süre hayatta kalmayı başarmışlardır. ${ }^{50}$

Teoride siyasi çekişmelerin müzakere yoluyla çözümlenebilir olmasına rağmen, dördüncü dalgada ortaya çıkan terör örgütlerinin temel motivasyonu tartışlamaz din ve Allah'ın emirleri olunca, devletlerin bu çatışmayı sona erdirecek şekilde teröristlerin taleplerini karşılamaları da mümkün olamamakta, terör örgütleri de bu tartış1lamaz doğalarının ${ }^{51}$

49 Jeffrey Kaplan ve Christopher P. Costa, "The Islamic State and the New Tribalism", Terrorism \& Political Violence, 2015 27(5), s.930-934

${ }^{50}$ Jeffrey Simon, "Technological and Lone Operator Terrorism: Prospects for a Fifth Wave of Global Terrorism", Terrorism, Identity and Legitimacy, ed. Jean E. Rosenfeld. N, Routledge 2010, s.49.

${ }^{51}$ Jonathan Fox, "The Future of Religion and Domestic Conflict," ed. Berma Klein Goldewijk, Religion, International Relations and Development Cooperation, 
Modern Terörizmin Beşinci Dalgası:

Devletlerin Uluslararası Terörist Örgütlerle İş Birliğinin Sebepleri ve Sonuçları?

etkisiyle kalıcı güç olarak varlıklarını sürdürebilmektedir. ${ }^{52}$ Grup ideolojilerinin netleşmesi ve bu ideoloji temelinde kurulacak terör grubu modellerinin ortaya çıkması yıllar alabileceğinden, bir dalganın bitip bir diğer dalganın başlama zamanını tam olarak belirleyebilmek mümkün değildir. $\mathrm{Bu}$ kapsamda beşinci terör dalgasının dayanacağ olay ve şartlar ortaya çıktığında, yeni bir akımın başlaması mümkün hale gelebilecektir. ${ }^{53}$ Ancak, Rapoport'un teorik olarak tanımladığı yeni bir terör dalgasının ortaya çıkması durumunda bile, radikal dinci terör dalgasındaki terör örgütlerinin uzun ömürlü olmaları ve yüksek oranda şiddet uygulamaları nedeniyle dördüncü dalganın öngörülen 20202025 yılları arasında sona ereceği kesin olarak söylenememektedir. ${ }^{54}$

Halen dördüncü dalga çerçevesinde ele alınan terör örgütleri arasında etkisi ve eylemleri devam edenlerin bulunmasına rağmen, yeni ve farklı bir terör dalgasının başladığını savunan çalışmalar da mevcuttur. Kaplan, beşinci terör dalgasındaki terör örgütlerinin amacının, etnik bir kökeni esas alan kabile toplumu yaratmak için, kaybolmuş bir modelden yeniden inşa edilen ya da tamamen yeniden yaratılan bir dünya düzeni kurmak olduğunu savunmaktadır. ${ }^{55}$

Yeni kabilecilik olarak adlandırılan beşinci terör dalgasının başladığını iddia eden Jeffrey Kaplan, Rapoport'un dalga teorisini genel olarak desteklemekte ancak terörizmin dinamik yapısının dikkate alınmadığ1 statik bir teori olarak görmektedir. ${ }^{56}$ Rapoport'a göre yeni bir terör dalgasının başlamasına sebep olacak tetikleyici uluslararası olaylar, Kaplan'a göre dördüncü dalga terör gruplarının devam etmesi

Wageningen Academic Publishers, Wageningen 2007, s.149.

52 Jeffrey Kaplan, Terrorist Groups and the New Tribalism, Routledge, New York 2010, s. 26.

53 Leonard Weinberg and William Eubank, "An End to the Fourth Wave of Terrorism?", Studies in Conflict \& Terrorism 33, no. 7, 2010, s. 601.

${ }^{54}$ A.g.e, s. 598.

55 Jeffrey Kaplan, “Terrorism's Fifth Wave: A Theory, a Conundrum and a Dilemma", Perspectives on Terrorism, no. 2, Ocak 2008, s. 12.

${ }^{56}$ Kaplan, 2010, s. 46. 
930

Güvenlik Stratejileri

Cilt: 16

Sayı: 36

nedeniyle söz konusu olmamaktadır. ${ }^{57}$ Beşinci terör dalgası olarak görülen dalgadaki terör örgütlerinin özellikleri olarak sayılabilecekler şunlardır:

1- Daha önceki bir terörizm dalgasındakilerle ortak inançlara sahiptirler, ancak sonradan radikalleşerek onlardan koparlar,

2- Aşırı olarak ifade edilen hedef ve umutlarının kaybolması ya da gerçekleşmesi nedeniyle ortaya çıkarlar,

3- Radikalleşme nedeniyle aynı görüşlere sahip benzer gruplardan ayrilma sonucunda, aile ve toplumdan uzaklaşırlar,

4- Sifirdan bir yol haritasi ve takvim belirlerler,

5- Eski dünyanın kirlendiğine ve gelecekteki saf toplumu yaratmak için mevcut insan yaşamının yok edilmesinin gerekli olduğuna inanirlar,

6- Uzlaşmanın mümkün olmadığı ve iç çatışmalara ve şiddete yol açacak şekilde bölünmelere son derece yatkınlardır,

7- İnsanın mükemmelliğine inandıkları için aynı nesil içerisinde bu mükemmellikte yeni kadın ve erkekler yaratmayı amaç edinirler,

8- Yeni toplum arayışları, işledikleri cinayetlerin cezasız kalmasına hatta soykırıma neden olur,

9- Vermek istedikleri asıl mesajı unutturacak kadar yaygın şiddet uygularlar,

10- Hedefledikleri yeni insan modelini yaratacak olmaları nedeniyle kadınlara özellikle boyun eğdirmeyi hedef alırlar.

11- Erkek çocukları askere almaya, kız çocukları çocuk gelin olmaya zorlarlar,

12- Tecavüz, uyguladıkları terörist taktiğin imzasıdır,

13- Kültürel normları ihlal etmeleri nedeniyle, teröristlerin aileye geri dönmeleri ve topluma yeniden katılabilmeleri zorlaşır,

${ }^{57}$ A.g.e, s. 47. 
Modern Terörizmin Beşinci Dalgası:

Devletlerin Uluslararası Terörist Örgütlerle İş Birliğinin Sebepleri ve Sonuçları?

14- Saf 1rkçılığı ve etnik merkeziyetçiliği esas alan, bölgesel milliyetçiliğe odaklanırlar,

15- Gelecekteki hedeflerine ulaşmak için gerekli ise yabancı müttefiklere faydacı bir yaklaşımla güven duyarlar,

16- Karizmatik liderlerin yönettiği oldukça otoriter yönetimleri vardir,

17- Dünyaya barış ve huzur getirecek Mesih'in geleceğine ve kıyamete inanırlar.

Kaplan, beşinci terör dalgasındaki örgütlere örnek olarak Kamboçya'daki Kızıl Kmerler terör örgütünü ve bu örgütün yönetime gelme mücadelesini vermektedir. ${ }^{58}$ Radikal dinci örgütler Kaplan'ın beşinci dalga terör örgütleri içerisinde yer almazken, Anthony Celso kendi ifade ettiği şekliyle "tekfirci-cihatçı" terör gruplarını ve özellikle de DÂİ̧̧'i beşinci dalga terör örgütleri içerisine dâhil etmekte ve bu örgütlerin Kaplan'ın belirlediği kriterlere uyduğunu iddia etmektedir. $\mathrm{Bu}$ farklı beşinci terör dalgası görüşüne göre; beşinci dalga terör örgütleri, hilafet devletinin kurulması için modern dünyayı tamamen dişlamakta ve Batı etkilerini yok etmeyi hedeflemektedir. ${ }^{59} \mathrm{Bu}$ gruplar içerisinde kendilerini Müslüman toplumundan ayıran özellikle Boko Haram ve DÂiŞ sahip oldukları aşırılık yanlısı inanç nedeniyle diğer Müslümanlara uygulanan şiddeti meşru görmekte, Müslümanların iç çatışmasını reddeden grupları da doğrudan hedef almaktadır.

Jeffrey Simon, Rapoport'un terör dalgaları teorisini desteklemekle beraber, ilk dört dalgadan oldukça önemli sapmalar gösteren beşinci bir dalgayı savunmaktadır. Simon, anarşizm, sömürgecilik karşıtlığ yeni sol/Marksizm ve köktendinci ideolojilerin önceki dört dalgaya hâkim olduğu gibi, terörist bir ideolojinin tek başına bütün beşinci dalgaya egemen olamayacağını, yeni terör dalgasının belirleyici özelliğinin

\footnotetext{
${ }^{58}$ Kaplan (2010), s. 61.

59 Anthony N. Celso, "The Islamic State and Boko Haram: Fifth Wave Jihadist Terror Groups," Orbis Volume 59 issue 2, 2015, s. 250-252, https://doi.org/10.1016/ j.orbis.2015.02.010, (Erişim tarihi; 20.09.2020).
}

\section{1}

Güvenlik Stratejileri

Cilt: 16

Say1: 36 
932

Güvenlik Stratejileri

Cilt: 16

Sayı: 36 teknolojinin etkili gücü olabileceğini iddia etmektedir. Beşinci terör dalgasını Teknolojik Dalga olarak adlandıran Simon'a göre, hükümetler, medya ve toplumun artık eskisi kadar ilgi göstermediği bir terör dalgasının sonu gelmiş demektir ve daha önemlisi, dinamitin modern terörün ve anarşist dalganın başlangıcındaki ön koşul olarak yerine getirdiği işlevi, beşinci dalgada internet yapmaktadır. ${ }^{60}$ Teknoloji hiçbir terör örgütünün tekelinde değildir ve bu durum örgütler arasındaki rekabet nedeniyle teknolojinin beşinci dalganın karakteristik özelliği olarak tanımlanmasını da sağlamaktadır. Beşinci dalgada, devletler ve devlet dış1 aktörler yanında, daha önceki terör dalgalarında sözü edilmeyen, yalnız çalışan ve eylemlerini tek başlarına planlayıp uygulayan terörist tipleri de dikkate alınmaktadır. "Lidersiz Cihat" da denilen bu çalışma yöntemi sanal ortamda radikalleşmenin ölçüsünü de arttırmaktadır. ${ }^{61}$ Bütün iletişim ve yönlendirmeler, eylem emirleri ve planlamaları internet ortamında gerçekleşmekte, böylece diğer örgüt üyeleri ile iletişim ve paylaşılan bir bilgi olmadığ örgütlerinin teröristlerin dijital izlerini takip etmeleri de zorlaşmaktadır. ${ }^{62}$

Beşinci bir dalganın başlamıș olduğu konusundaki çalıșmaların en belirgin ortak yanı, ilk dört dalganın varlığını ve teorik altyapısını kabul etmeleri ancak yetersiz bulmalarıdır. İdeolojik, teknik ya da kapsayıcılık olarak aslında önceki terör dalgalarından kesin çizgilerle farklılık yaratmayan beşinci dalga çalışmalarının her birini diğer terör dalgalarından en az birisinin kapsamına almak mümkündür. Kaplan'ın Yeni Kabilecilik olarak önerdiği beşinci terör dalgası, milliyetçi, yeni sol ya da radikal dinci dalgalardaki terör örgütlerinin bir ya da birden fazla özelliğine sahiptir. Kızıl Kmerler örgütünün milliyetçi, antiemperyalist, anti-kapitalist söylem ve fikirleri, silahsız sivillere karş1

${ }^{60}$ Jeffrey D. Simon, "Technological and Lone Operator Terrorism: Prospects for a Fifth Wave of Global Terrorism", Terrorism, Identity and Legitimacy, ed. Jean E. Rosenfeld, Routledge, New York 2011, s. 48.

${ }^{61}$ Marc Sageman, "Ripples in the Waves: Fantasies and Fashions", Terrorism, Identity and Legitimacy: The Four Waves Theory and Political Violence, ed. Jean E. Rosenfeld, Routledge, New York 2011, s. 90.

${ }^{62}$ Simon, age, s. 56. 
Modern Terörizmin Beşinci Dalgası:

Devletlerin Uluslararası Terörist Örgütlerle İş Birliğinin Sebepleri ve Sonuçları?

uyguladığ1 şiddet yöntemleri bu özellikler arasında sayılabilir. Aynı şekilde, Anthony Celso'nun beşinci dalga terör örgütü olarak tanımladığı "Tekfirci-Cihatçı Terör Örgütleri” özellikle dördüncü dalganın devamında sadece şekil, söylem ve eylem farklılıkları gösteren aslında aynı kategorideki radikal dinci örgütler olarak ortaya çıkmaktadır. Teknolojik beşinci dalga konusunu ileri süren Simon'un değerlendirmesine göre internetin kullanımı bile aslında tek başına bir terör dalgası olma özelliklerini taşımaktadır. Ancak, teknolojinin kullanımı sadece internet ile sınırlandırmak yerine, her terör dalgasında gerek eylemlerde kullanılan yöntemlerin, gerekse kullanılan silah araç ve gereçlerin de teknolojik gelişmeden etkilendiğini (dinamit kullanımından el yapımı patlayıcılarda kullanılan düzeneklere, altıpatlar tabancadan, biyolojik silahlara uzanan süreç) kabul etmek daha uygun olacaktır. ${ }^{63}$

\section{Modern Terörün Beşinci Dalgası Olarak Devletlerle Ortaklık}

Rapoport'un teorisine göre bir terör dalgasının başlamas1, kendisine özgü tetikleyici ya da eylem sürecini hızlandırıcı olaylar ile olacak ve imza niteliğindeki taktikleri ile silahları bulunacaktır. Terörist eylemlerin bir terör dalgası olarak değerlendirilmesinde esas alınan önemli bir değişken de, bir sonraki terör dalgasının ortaya çıkmasına sebep olan kaçınılmaz bir kademeli düşüş döneminin görülmesidir. ${ }^{64}$

Daha önce beşinci terör dalgası olarak önerilen terör hareketlerinin, ilk dört terör dalgasının başlayıp devam etmesi süreçlerinde söylem ve yöntem yönünden benzerlikleri dikkate alındığında yaşanan örtüşme, dördüncü terör dalgasının devamında yaşanan bu terör dalgasına karşı yürütülen küresel mücadele döneminde, devletlerin terör örgütleriyle ittifak kurmak suretiyle kendileri için asıl tehdidi teşkil ettiklerini değerlendirdikleri dördüncü dalgadaki terör örgütlerine karşı iş birliğine girmeleri döneminde yaşanmamıştır. Bir terör örgütüne karşı diğer bir terör örgütü ile doğrudan ve açıkça yapılan iş birliği sonucunda yeni

\footnotetext{
${ }^{63}$ Mesut Hakkı Caşın, Uluslararası Terörizm, Nobel Yayın Dağıtım, Ankara, 2008, s. $90-100$.

${ }^{64}$ Kaplan (2016), s. 4.
}

\section{3}

Güvenlik Stratejileri

Cilt: 16

Say1: 36 

için bir imza niteliğinde olduğu, böylece yeni bir terör dalgasının başladığı değerlendirilmektedir. Terör örgütleri için nihai hedeflerine ulaşmak amacıyla uygulayacakları bütün değişim ve dönüşümler şiddet kullanmalarına meşruiyet kazandırmanın yanı sıra, meşru bir devletin açık desteğini almış olmaları nedeniyle de kamuoyu muhalefetine tedbir getirmektedir. ${ }^{65}$

$\mathrm{Bu}$ çalışmada, modern terörün beşinci dalgası, "Devletlerin Terör Ortaklığı" ya da "Terörle İttifak" olarak adlandırılmaktadır. Bu çerçevede, ABD'nin Suriye İç Savaşı sırasında DÂi̧̧̇'le mücadele adı altında PKK terör örgütünün Suriye'deki uzantısı olan YPG ile iş birliği örnek olarak verilebilecektir. ${ }^{66} \mathrm{ABD}$ bu dalganın kilit ülkesi durumundadır, ancak Rusya'nın da Ukrayna ile yaşadığı ve çatışma ile sonuçlanan siyasi kriz döneminde Rus azınlığın yaşadığ 1 bölgelerde ayrılıkçı terör hareketi eylemlerini Rus özel kuvvetleri vasıtası ile desteklediği ve gerçekleştirdiği de bir gerçektir. ${ }^{67}$ Yine geçmişte ve günümüzde devletlerin ulusal çıkarları nedeniyle hasım devletleri zayıflatmak amacıyla terör örgütleriyle gizli olarak iş birliği yaptı̆̆ eğitim, malzeme, silah, araç, gereç ve para yardımında bulunduğu bilinmektedir. Ancak yeni terör dalgasının temel özelliği, bu destek ve iş birliğinin devlet tarafından açık olarak ve terör örgütünün yasal, örgütün faaliyetlerinin de meşru kabul edilerek yapılıyor olmasıdır.

11 Eylül terör saldırılarında terör ve terörizmle kendi anavatanında karşılaştıktan sonra, küresel terörle mücadele adı altında bir girişim başlatan, ancak kendi ulusal çıkarları nedeniyle, terör örgütleri ile iş birliğini açık olarak sürdüren $\mathrm{ABD}$ bugün karşılaşılan terör

65 Brian Michael Jenkins, The New Age of Terrorism, McGraw-Hill Homeland Security Handbook, s. 120-121.

${ }^{66}$ Can Acun ve Bünyamin Keskin, The PKK'S Branch in Northern Syria PYD-YPG, SETA, 2017, s. 18, https://setav.org/en/assets/uploads/2017/05/PYD_YPG_En.pdf (Erişim tarihi; 10.10.2020).

67 International Court of Justice, Terrorism Financing and Racial Discrimination in Ukraine, Application Instituting Proceedings, 16 January 2017, s. 9-22, https://www.icjcij.org/files/case-related/166/19314.pdf, (Erişim tarihi; 09.10.2020) 
Modern Terörizmin Beşinci Dalgası:

Devletlerin Uluslararası Terörist Örgütlerle İş Birliğinin Sebepleri ve Sonuçları?

hareketlerinin kaynağını, 2006 yılı Ulusal Güvenlik Stratejisi Belgesinde şöyle açıklamıştır: ${ }^{68}$

1- Siyasi yabancılașma: Uluslararası terör örgütleri, kendi ülkelerinde yasal meşru yollardan yönetimin değişmesini sağlayamayan ya da hükümetlerine seslerini duyuracak şekilde siyaseten temsil edilmeyen halk kitlelerinden eleman temin etmeyi tercih ederler. Zira mevcut düzende bu gibi kişiler bir destekleri olmadıkça sapık ideoloji sahibi şiddet ve tahribat yanlısı terör örgütlerinin manipülasyonuna açık ve savunmasız durumdadır.

2- Her zaman başkalarını suçlayarak şikâyet etmek: Bazen yakın bazen de uzak geçmişte yaşanan bütün yanlışlıklar ve adaletsizlikler nedeniyle diğerlerini suçlarlar. Böylece intikam ve terör eylemleri için gerekli olan motivasyonu her zaman canlı ve taze tutmayı amaçlarlar.

3- Komplo ve yanlış bilgilendirme yapmak: Bu yöntemi kullanan terör örgütleri yanlış bilgilendirme ile kirletilmiş ya da komplo teorileri ile çarpıtılmış, ayartılmış ve algı yönlendirmesi ile kandırılmış toplumlardan etkili bir katılım sağlayabilmektedir.

4- Uğruna insan öldürmeyi, bir anlamda cinayet işlemeyi meșru kabul eden bir ideolojinin olması: Terörizm, insanların dini inançlarını da çarpıtmak suretiyle, masum insanların öldürülmesine mazeret hatta onurlandırma sağlayan ideolojilere dayanabilmektedir. ${ }^{69}$

ABD'nin, Bush imzalı 2006 yılı Ulusal Güvenlik Stratejisi belgesinde, Terörle Savaş'ın bir dinle savaş olmadığı, teröristlerin bütün dinleri hedef aldığı, etnik ve dini kökenli terör örgütlerinin de en çok kendi toplumlarına zarar verdiği değerlendirilmekte, yine Obama döneminin 2015 yılı Ulusal Güvenlik Stratejisi belgesinde de, bir bütün olarak terör tehdit kabul edilerek, müttefikler ve sorumluluk duyan

\footnotetext{
${ }^{68}$ ABD 2006 Ulusal Güvenlik Strateji Belgesi, s.10.

${ }^{69}$ Biçer (2019), s. 122.
}

\section{5}

Güvenlik Stratejileri

Cilt: 16

Say1: 36 
ortaklarla birlikte, terörün radikalliğinden ve şiddetinden korunmak amacıyla teröre karşı sürekli mücadelenin esas alınacağına işaret

Güvenlik Stratejileri

Cilt: 16

Sayı: 36 edilmektedir. ${ }^{70}$ ABD'nin 2017 yılı sonunda yayınlanan Ulusal Güvenlik Strateji belgesinde ise terör tehdidi olarak sadece cihatçı terörist örgütler vurgulanmakta ve metnin başka hiçbir yerinde ne küresel terör tehdidinden, ne de ayrılıkçı ya da marjinal ideolojik kökenli terör örgütlerinden $\mathrm{ABD}$ için bir tehlike olarak söz edilmemektedir. ABD Başkanı Trump döneminin güvenlik stratejisine göre artık Amerikalılara zarar verme olasılığı olan sadece cihatçı terör örgütleridir. Bundan daha da önemlisi ise, ABD'nin terör örgütleri listesinde yer alan 61 terör örgütünden cihatçı olmayanların $\mathrm{ABD}$ yasalarındaki terör örgütlerine uygulanacak yaptırımlardan etkilenmeyecekleri yönünde bir niyet olmasıdır. ABD Savunma Bakanlığı web sayfasındaki yabancı terör örgütleri listesinin hemen alt kısmında Göçmenlik ve Uyruk Kanunu'nun (INA) madde 219 'da yapılan düzeltmeye istinaden; "terör örgütlerinin faaliyetleri $\mathrm{ABD}$ vatandaşlarını ya da $\mathrm{ABD}$ ulusal güvenliğini tehdit etmelidir" denilmektedir. Bu durumda, bir yabancı terör örgütü eğer ABD çıkarlarına hizmet ediyorsa, listede yazılı olan ismini değiştirdiği ya da listede adı olmayan başka bir örgütle birleşerek birlikte hareket ettiğinde, ABD için strateji belgesinde tanımı yapılan; "Dürüstlük, karşılıklılık ve sadakatle bağllık temelinde, ABD ile aynı fikir ve düşüncede olan, $\mathrm{ABD}$ prensiplerini geçerli, kurallarını zorunlu kabul eden ortaklar" arasında yerini alacaktır. Yani, ABD'nin çok ters ve anlaşılmaz olarak kabul edilen, terör listesinde yer alan PKK'nın uzantısı olduğu artık kesinleşmiş durumdaki YPG/PYD terör örgütüne açıkça silah, araç, gereç ve eğitim desteği vermesi, ABD Ulusal Güvenlik Stratejisi'nin gereğidir. $\mathrm{Bu}$ uygulama, Rapoport'un terör dalgalarının bir devamı olarak devletlerin terör örgütleri ile iş birliği yapmasının ötesinde meşru sayılabilecek ortakl1klar kurması kapsamında değerlendirilmektedir.

Terör örgütleri bakımından ise, ideoloji, etnik yapı ya da dinmezhep temelinde savundukları ve kuruluş gerekçelerini dayandırdıkları argümanlar eğer hedeflerinin gerçekleşmesi için bekledikleri başarıya

${ }^{70}$ ABD 2015 Ulusal Güvenlik Strateji Belgesi, s. 10-11. 
Modern Terörizmin Beşinci Dalgası:

Devletlerin Uluslararası Terörist Örgütlerle İş Birliğinin Sebepleri ve Sonuçları?

ulaşmalarını geciktiriyor ya da engelliyorsa, yeni bir açılım olarak farklı modeller deneyebilme esnekliği göstermeleri yeni terör dalgasının bir özelliği olarak karşımıza çıkmaktadır. Aynı örnek üzerinden giderek PKK terör örgütünün Marksist-Leninist ve 1rkçı çizgisini, Suriye'nin Kuzeyinde DÂIȘ'le mücadele adı altında ABD başta olmak üzere DÂIŞ terörü nedeniyle ulusal güvenliğini tehdit altında gören ülkelerin vekili olarak savaşması halinde kazanımlarını değerlendirip yeniden gözden geçirdiğini, sonrasında örgütün ırkçı çıkarları için anti-emperyalist çizgisinden saptığını ve ideolojik olarak düşman olması gereken devletlerle müttefik olduğunu görülebilmektedir. $\mathrm{Bu}$ dönüşüm, terör örgütlerinin yeni bir yöntem ile eylemlerindeki önceliklerini ittifak kurduğu devletlerin birinci öncelikli tehdit kabul ettiği diğer bir terör örgütüne yöneltip, asıl terör eylemlerini yöneltecekleri örgüt hedeflerinin meşruluğunu sağlamayı hedeflemektedir.

Aşağıdaki tabloda görüleceği gibi, terörle ittifak nedenleri, amaç ve hedefler ile bu dönemde uygulanan terörist taktikleri ve kullanılan silah araç gerecin özelliklerini dikkate aldığımızda;

1- Devletlerin terör örgütleri ile açık ittifaklar kurmasının nedenleri arasında en önemlisi; bu devletlerin ulusal çıkarları ile terör örgütünün örgütsel çıkarlarının belli bir dönem için de olsa örtüşüyor olmasıdır. Devletlerin diğer devletlerle ilişkileri ortak çıkarlar temelinde nasıl şekilleniyorsa, terör örgütleriyle de iş birliğini aynı esaslara göre düzenlemek özellikle terör örgütünün hedefleri arasında olmayan devletler için tercih edilen bir vekâlet savaşı yöntemi haline gelmiştir. Bir devletin vekili olarak sahada savaşan bir terör örgütü için ise örgütün hedeflerine uzun vadede hizmet edecek bir ittifakın diğer terör örgütleriyle yapıldığı gibi, bir devletle yapılmasında da herhangi bir kayıp bulunmamaktadır.

2- Devletin amacına hizmet edecek terör örgütünün terör eylemlerini devletle ittifak kurulan alan dışında devam ettirmesi mümkün ise, esas örgütsel amaçlarda bir sapma olmaksızın devletin vekili olma görevi yerine getirilecek, bu sayede silah araç ve gereç bakımından güçlenerek ittifak alanı dışındaki terörist faaliyetleri icra ederken daha güçlü hale gelinecektir. 
938

Güvenlik Stratejileri

Cilt: 16

Say1: 36
$\mathrm{Bu}$ husus özellikle de ittifak kurulan devletin, terör örgütünün eylem hedefi olan ülkelerle ilişkisinin seyrine göre teröristlere önemli avantajlar sağlayabilecektir.

3- İttifak hedefleri öncelikli ortak hedefler üzerinden belirlenecek, dönemsel olarak terör örgütünün ve devletin hedef öncelikleri aralarındaki bir mutabakatla değişebilecektir. Suriye İç Savaşında DÂIŞ'le mücadele YPG/PKK ve ABD için ortak payda olmuştur. Türkiye, Rusya ve İran'ın bölgedeki iş birliğinin ve sürdürdükleri faaliyetlerinin gerek ABD'nin gerekse YPG/PKK terör örgütünün çıkarları açısından bir tehdit olarak değerlendirilmesi sonucunda ise, sadece DẦiş terör örgütünü hedef alan bir iş birliği değil, bu örgüt etkisiz hale getirildikten sonra da bölgedeki güç kontrolüne etki edecek bir ittifaka dönüşmüştür.

4- Devlet ve terör örgütünün iş birliği sürecinde, her iki taraf da, aralarındaki ittifakın bozulmasına sebep olmayacak şekilde iş birliği konuları ve ittifak alanından bağımsız olarak kendi hedefleri doğrultusundaki diğer uygulamalarına devam edebilecek, ancak bu konuda yapılacak düzenlemelerde esas söz sahibi terör örgütü değil devlet olacaktır. Terör örgütü içerisindeki örgüt yönetici kadrosuna muhalif ya da kontrol edilemeyen grupların varlığı biliniyorsa, bu grupların ittifak hedeflerine zarar vermesini engellemek için gerektiğinde tasfiye amacıyla infaz ve dışlama yöntemleri kullanılacaktır.

5- Terör örgütüne mensup teröristlerin eğitim ve donatımı ile doğrudan maddi destek sağlama konusunda devletin uluslararası ortamın gereği olarak zaman zaman gösterebileceği isteksizlik ya da değişiklik sonucunda, terör örgütünün de ortak hedeflere yönelimini yeniden değerlendirip, vekâlet görevini sona erdirme tehdidinde bulunması beklenmelidir. Suriye İç Savaşı sırasında ABD'nin Suriye'den askerî güçlerini tamamen çekeceğini açıkladığı dönemde, YPG/PKK terör örgütünün de Türkiye'nin kendisine yönelik icra edeceği muhtemel bir harekât nedeniyle DÂIŞ terör örgütü ile mücadeleyi sona erdireceğini ve cezaevlerindeki DÂIŞ̧'li teröristleri serbest 
bırakacağını açıklaması, bu şekildeki ittifakların hassasiyetleri 939 olarak değerlendirilmelidir.

6- Terör örgütü, müttefiki devletin konvansiyonel yöntemlerle baş edemediği tehdide karşı kendi eylem yöntemi olan gerilla harbini karma bir çatışma uygulaması şeklinde vekili olduğu Güvenlik Stratejileri Cilt: 16 devletin teknolojik ve lojistik imkânları ile birleştirerek kullanacak, böylece gerek personelinin bireysel eğitimini gerekse asıl nihai amacına yönelik olarak örgütün topyekûn eylem stratejisini geliştirecektir. Devlet terör örgütü iş birliğinde teröristlerin en önemli kazanımlarından birisi olarak değerlendirilebilecek bu husus, beşinci dalga terör eylemlerinin ilerde yeni terör dalgalarının gelişmesindeki katkısının da bir işareti olarak kabul edilebilecektir. 
940

Güvenlik

Stratejileri

Cilt: 16

Sayı: 36
Tablo-1 Modern terörün beş dalgasının özellikleri ${ }^{71}$

\begin{tabular}{|c|c|c|c|c|c|}
\hline $\begin{array}{c}\text { TERÖR } \\
\text { DALGASI }\end{array}$ & $\begin{array}{l}\text { KATKIDA } \\
\text { BULUNAN } \\
\text { SEBEPLER } \\
\end{array}$ & AMAÇ & HEDEFLER & TAKTÍKLER & $\begin{array}{l}\text { GERILEEME } \\
\text { NEDENI }\end{array}$ \\
\hline $\begin{array}{l}\text { Anarşist } \\
\text { 1870ler- } \\
\text { 1910lar }\end{array}$ & $\begin{array}{l}\text { Yavașlayan siyasi } \\
\text { reformlar ve } \\
\text { düşüșe geçen } \\
\text { monarşi düzeni }\end{array}$ & $\begin{array}{c}\text { Devrim, } \\
\text { hükümetin } \\
\text { baskısını ortadan } \\
\text { kaldırmak }\end{array}$ & $\begin{array}{c}\text { Devleti } \\
\text { yönetenler }\end{array}$ & $\begin{array}{c}\text { Patlayıcı } \\
\text { kullanarak } \\
\text { gerçekleștirilen } \\
\text { suikastler ve } \\
\text { banka soygunları }\end{array}$ & $\begin{array}{c}\text { Sertleșen devlet } \\
\text { müdahaleleri ve } \\
\text { Birinci Dünya } \\
\text { Savaşının } \\
\text { bașlaması }\end{array}$ \\
\hline $\begin{array}{l}\text { Milliyetçi } \\
\text { 1920ler- } \\
\text { 1960lar }\end{array}$ & $\begin{array}{c}\text { Versay Barış } \\
\text { Antlașmasi, artan } \\
\text { self- } \\
\text { determinasyon } \\
\text { talepleri } \\
\end{array}$ & $\begin{array}{c}\text { Sömürge düzenini } \\
\text { ortadan kaldırmak } \\
\text { ve yeni devletler } \\
\text { kurmak }\end{array}$ & Polis ve askerler & $\begin{array}{c}\text { Gerilla } \\
\text { yöntemleri ve } \\
\text { vur-kaç taktikleri }\end{array}$ & $\begin{array}{c}\text { Sömürgeci } \\
\text { devletlerin geri } \\
\text { çekilmesi ve } \\
\text { amaçların } \\
\text { gerçekleșmesi }\end{array}$ \\
\hline $\begin{array}{l}\text { Yeni Sol } \\
\text { 1960lar- } \\
\text { 1980ler }\end{array}$ & $\begin{array}{l}\text { Vietnam Savaşı ve } \\
\text { Soğuk Savaş } \\
\text { gerilimleri }\end{array}$ & $\begin{array}{c}\text { Kapitalist } \\
\text { sistemin ortadan } \\
\text { kaldırılması }\end{array}$ & $\begin{array}{c}\text { Hükümetler, } \\
\text { özellikle de } \\
\text { ABD üzerinde } \\
\text { odaklanma }\end{array}$ & $\begin{array}{l}\text { Uçak kaçırma, } \\
\text { adam kaçırma ve } \\
\text { suikastler. }\end{array}$ & $\begin{array}{l}\text { Soğuk Savaşın } \\
\text { sona ermesi }\end{array}$ \\
\hline $\begin{array}{c}\text { Radikal Dinci } \\
\text { 1979-2020ler } \\
\text { (tahmini) }\end{array}$ & $\begin{array}{c}\text { İran İslam } \\
\text { Devrimi, } \\
\text { Sovyetlerin } \\
\text { Afganistanı işgali }\end{array}$ & $\begin{array}{c}\text { Küresel Hilafet } \\
\text { Devletinin } \\
\text { kurulması }\end{array}$ & $\begin{array}{c}\text { ABD, İsrail, } \\
\text { Avrupa, kitle } \\
\text { ulașım araçları, } \\
\text { halka açık } \\
\text { mekanlar }\end{array}$ & İntihar eylemleri. & Bilinmiyor \\
\hline $\begin{array}{l}\text { Terörle } \\
\text { İtifak } \\
2016-\end{array}$ & $\begin{array}{l}\text { ABD bașta olmak } \\
\text { üzere devletlerin } \\
\text { ulusal çıarlarına } \\
\text { tehdit teşkil eden } \\
\text { önceki dalgaların } \\
\text { süren etkisi }\end{array}$ & $\begin{array}{c}\text { Devletlerin hedefi } \\
\text { ulusal çıarlarını } \\
\text { gerçekleștirmek, } \\
\text { terör örgütlerinin } \\
\text { hedefi yakın, orta } \\
\text { ve uzun vadeli } \\
\text { hedeflerine } \\
\text { ulașmak için } \\
\text { devletlerle ittifak } \\
\text { kurmak }\end{array}$ & $\begin{array}{c}\text { Devletlerin } \\
\text { ulusal } \\
\text { çikarlarına } \\
\text { hizmet edecek } \\
\text { her hedef, terör } \\
\text { örgütünün } \\
\text { hedefleri ile } \\
\text { örtüșenlere } \\
\text { özellikle } \\
\text { odaklanma }\end{array}$ & $\begin{array}{l}\text { Düzenli harp ve } \\
\text { gerilla harbi } \\
\text { yöntemleri karma } \\
\text { olarak } \\
\text { uygulanmaktadır. }\end{array}$ & Bilinmiyor \\
\hline
\end{tabular}

\section{Sonuç}

Terör örgütleri ile devletlerin ittifak içerisine girmesi, gerek uluslararası güvenlik gerekse terörist tehdit altındaki ülkelerin ulusal güvenlikleri bakımından önemli bir sorundur. Böyle hassas bir konuda

${ }^{71}$ Kaynak olarak; Erin Walls, "Waves of Modern Terrorism: Examining the Past and Predicting the Future", Georgetown Üniversitesi Yüksek Lisans tezi, Washington Nisan 2017, s. 20'deki tablo-1 esas alınmış ve önerilen beşinci dalga özellikleri tabloya ilave edilmiştir. 
Modern Terörizmin Beşinci Dalgas1:

Devletlerin Uluslararası Terörist Örgütlerle İş Birliğinin Sebepleri ve Sonuçları?

geleneksel ve tarihsel güvenlik anlayışını terk ederek, ulusal çıkarlarını kısa vadeli ittifaklara yönelten devletlerin orta ve uzun vadede aynı terör tehdidinden etkilenmesi kaçınılmazdır. Bugün gelinen noktada terörizmin beşinci dalgasının sona ermesi ile ilgili bir emare görülmemektedir. Terör örgütlerinin devletlerle açık ittifak kurduğu günümüz uluslararası güvenlik ortamının kaotik yapısı, ilerde muhtemelen yeni bir terör dalgasının ortaya çıkması ile devam edecek, ancak terör örgütleri ile ulusal çıkarları nedeniyle açık iş birliğine giren ülkelerin, ABD başta olmak üzere güvenilirlikleri her zamankinden daha fazla sorgulanacak, hatta bu devletler özellikle müttefik oldukları devletlerin ulusal siyaset organlarında ve kamuoylarında siyaseten yargılanacaktır.

\section{Summary}

In his article written in 2004, David Rapoport examined the waves of international terrorist movements in the historical process and explained what terrorism means in terms of international relations theoretically and conceptually. Today, at the point where international terrorism has come, a new wave of terrorism represents a process in which states use terrorism for the sake of their national interests in the anarchic structure of the field of international relations, and attempt to legitimize cooperation with terrorist organizations and groups as a different form of war. According to Rapoport, Four Waves of Modern Terror defines a cycle that takes place over a period of forty years as a wave. Terrorist groups taking part in a wave during this period are aware of the actions of all different terrorist groups, which are their contemporaries in other countries, as well as using a common technology, including communication methods, weapons and logistics resources and methods, and more importantly, the world's They share a vision that perceives all the negativities they face as the seeds of a revolutionary future.

Some academic studies have been made to suggest that a fifth wave of terror is coming right after Rapoport's four waves of terror. The most obvious common feature of these studies is that they accepted the existence and theoretical background of the first four waves but found them insufficient. It is possible to include each of the fifth wave studies, 
which do not make a distinct difference from previous terror waves in

Güvenlik Stratejileri

Cilt: 16

Sayı: 36 terms of ideological, technical or inclusiveness, in at least one of the other terror waves. Considering the similarities in terms of rhetoric and methodology of the terrorist movements, which were previously suggested as the fifth terrorist wave, in the process of starting and continuing the first four terrorist waves, the overlap did not occur during the period of the global struggle against this terror wave experienced in the continuation of the fourth wave of terrorism. The cooperation of the states against terrorist organizations in the fourth wave, which they consider as the main threat to them by forming alliances with terrorist organizations, appears as a new method of combating terrorism in this period. It is evaluated that a new wave of terror has been triggered and accelerated as a result of direct and open cooperation with another terrorist organization in order to fight against a terrorist organization that this alliance is a signature for terrorist organizations, and thus a new wave of terror has started.

The alliance between terrorist organizations and states is an important problem both in terms of international security and the national security of countries that they are under terrorist threat. In such a sensitive issue, it is inevitable for states that abandon traditional and historical security understanding and turns their national interests to short-term alliances with terrorists, to be affected by the same terrorist threat in the medium and long term. Today, there is no sign of the end of the fifth wave of terrorism. The chaotic nature of today's international security environment, in which terrorist organizations open alliances with states, will probably continue with the emergence of a new wave of terrorism in the future, but the credibility of countries, especially the United States, that have open cooperation with terrorist organizations due to their national interests, will be questioned more than ever, even these states will be judged politically, especially in their own national political organs and public opinion of the states which they are allies with. 
Modern Terörizmin Beşinci Dalgası:

Devletlerin Uluslararası Terörist Örgütlerle İş Birliğinin Sebepleri ve Sonuçları?

\section{Kaynakça \\ Kitaplar}

ABD 2006 Ulusal Güvenlik Strateji Belgesi.

ABD 2015 Ulusal Güvenlik Strateji Belgesi.

BERTI Benedetta, Armed Political Organizations: From Conflict to Integration, Baltimore Johns HOPKINS University Press, 2013.

BRODIE Bernard, War and Politics, Macmillan, New York, 1973.

CAŞIN Mesut Hakkı, Uluslararası Terörizm, Nobel Yayın Dağıtım, Ankara, 2008.

CLARKE Thrustone, By blood and Fire: The Attack on the King David Hotel, Hutchinson, London 1981.

COOPER John Milton, Woodrow Wilson: A Biography, Knopf Doubleday Publishing Group, New York 2009.

FOX Jonathan, "The Future of Religion and Domestic Conflict," Religion, International Relations and Development Cooperation, ed. Berma Klein Goldewijk, Wageningen Academic Publishers, Wageningen 2007.

HOFFMAN Bruce, Inside Terrorism, Columbia University Press, New York, 2006.

JANKOWSKI James P., Nasser's Egypt, Arab Nationalism, and the United Arab Republic, Lynne Rienner Publishers, Colorado Boulder 2001

LAW Randall D., The Routledge History of Terrorism, Routledge, New York, 2015.

JENKINS Brian Michael, The New Age of Terrorism, McGraw-Hill Homeland Security Jerryson Handbook Chapter 8.

KHALIDI Rashid, Palestinian Identity: The Construction of Modern National Consciousness, Columbia University Press, New York, 2010.

KAPLAN Jeffrey, Beyond the Mainstream: The Emergence of Religious Pluralism in Finland, Estonia, and Russia, SKS, Helsinki, 2000.

KAPLAN Jeffrey, Terrorist Groups and the New Tribalism, Routledge, New York 2010.

MAKOWSKI Krzysztof A. ve Frank Hadler, Approaches to Slavic Unity: Austro-Slavism, Pan-Slavism, Neo-Slavism, and Solidarity among the Slavs Today, Poznan, 2013.

McCORMICK Gordon H., "Terrorist Decision Making", Annual Review of Political Science 6, 2003.

SAGEMAN Marc, "Ripples in the Waves: Fantasies and Fashions", Terrorism, Identity and Legitimacy: The Four Waves Theory and Political Violence, ed. Jean E. Rosenfeld, Routledge New York, 2011.

SAGEMAN Marc, Leaderless Jihad: Terror Networks in the Twenty-First Century, Philadelphia University of Pennsylvania Press 2008.

RAMET Sabrina Petra, Rocking the State: Rock Music and Politics in Eastern Europe and Russia, Westview, Colorado Boulder, 1994.

RAPOPORT David C., "Terror and the Messiah: An Ancient Experience and Some Modern Parallels." The Morality of Terrorism: Religious and Secular Justifications, Ed. D. C. RAPOPORT ve YONAH, Alexander, Columbia University Press, New York, 1982.

RAPOPORT David C., "The Four Waves of Modern Terrorism." Attacking Terrorism: Elements of a Grand Strategy, Ed. CRONIN, Audrey Kurth ve KUDES, James M., Georgetown University Press, Washington DC, 2004. 


\section{Rüştü Salim Savaş BİÇER}

944

Güvenlik Stratejileri

Cilt: 16

Sayı: 36

RAPOPORT David C., "The Four Waves of Modern Terror: International Dimensions and Consequences", An International History of Terrorism: Western and Non-Western Experiences, Ed. J. M. Hanhimäki ve B. Blumenau, Routledge, London, 2013.

SHULTZ Richard.H. ve GODSON, Roy, Dezinformatsia: Active measures in Soviet strategy, Pergamon-Brassey's, Washington, 1984.

SCALAPINO Robert A. ve GEORGE T. Yu, The Chinese Anarchist Movement, Berkeley: Center for Chinese Studies, Institute of International Studies University of California, Califonia, 1961.

SCHMID Alex P., The Routledge Handbook of Terrorism Research, New York: Routledge, 2011.

SIMON Jeffrey D., "Technological and Lone Operator Terrorism: Prospects for a Fifth Wave of Global Terrorism", Terrorism, Identity and Legitimacy, ed. ROSENFELD, Jean E., Routledge, New York, 2011.

STERLING, Claire, The Terror Network: The Secret War of International Terrorism, Holt, Rinehart, and Winston, New York, 1981.

\section{Makaleler}

CRONIN, Audrey K., "Behind the Curve: Globalization and International Terrorism", International Security, Say1: 27/3.

BIÇER R.S. Savaş, "Uluslararası Çatışmaların Değişen Yapısında Terörün Yeri ve Önemi Üzerine Bir İnceleme”, Savunma Bilimleri Dergisi, Kasım 2019, Cilt 18/2, Say1 36.

FORTNA Virginia Page, "Do Terrorists Win? Rebels' Use of Terrorism and Civil War Outcomes", International Organization, Summer 2015, Say1: 69/3.

KAPLAN Jeffrey, "Terrorism's Fifth Wave: A Theory, a Conundrum and a Dilemma", Perspectives on Terrorism, no. 2, Ocak 2008.

KAPLAN, Jeffrey ve COSTA, Christopher P., "The Islamic State and the New Tribalism", Terrorism \& Political Violence, 2015 27/5.

RAPOPORT David C., "Moses, Charisma, and Covenant," The Western Political Science Quarterly, 1979, Sayı: 32/2.

RAPOPORT David C., "Messianic Sanctions for Terror", Comparative Politics, 1988, Say1: 20

RAPOPORT, David C. "Fear and trembling: Terrorism in three religious traditions", American Political Science Review, 1984. Say1: 78/3.

RAPOPORT David C., "The Four Waves of Rebel Terror and September 11", Anthropoetics, 2002, Sayı: 8/1.

KYDD Andrew H. ve BARBARA F. Walter, "The Strategies of Terrorism", International Security, 2006, Say1: 31/1.

WEINBERG Leonard ve WILLIAM Eubank, "An End to the Fourth Wave of Terrorism?", Studies in Conflict \& Terrorism, 2010, Say1: 33/7.

İnternet Kaynakları

ACUN Can ve KESKIN Bünyamin, The PKK'S Branch in Northern Syria PYD-YPG, SETA report, 2017, https://setav.org/en/assets/uploads/2017/05/PYD_YPG_En.pdf (Erişim tarihi; 10.10.2020) 
Modern Terörizmin Beşinci Dalgası:

Devletlerin Uluslararası Terörist Örgütlerle İş Birliğinin Sebepleri ve Sonuçları?

CELSO, Anthony N., "The Islamic State and Boko Haram: Fifth Wave Jihadist Terror Groups," Orbis Volume 59 issue 2, 2015, https://doi.org/10.1016/j.orbis.2015.02.010, (Erişim tarihi; 20.09.2020)

International Court of Justice, Terrorism Financing and Racial Discrimination in Ukraine, Application Instituting Proceedings, 16 January 2017, https://www.icjcij.org/files/case-related/166/19314.pdf, (Erişim tarihi; 09.10.2020)

HOFFMAN, Bruce, Al Qaeda, Trends in Terrorism, and Future Potentialities: An Assessment, Santa Monica, Rand Corporation, California 2003, https://www.rand.org/pubs/papers/P8078.html, (Erişim tarihi; 12 Eylül 2020)

KAPLAN, Jeffrey, "Waves of Political Terrorism", Summary and Keywords Waves of Political Terrorism, Oxford Research Encyclopedia of Politics, 2016, https://www.researchgate.net/publication/319910997_Waves_of_Political_Terrorism_ Summary_and_Keywords_Waves_of_Political_Terrorism_Oxford_Research_Encyclo pedia_of_Politics, (Erişim tarihi; 05 Eylül 2020)

MILLER, John, Greetings, America. My name Osama bin Laden, Frontline, 1999, https://www.esquire.com/news-politics/a1813/osama-bin-laden-interview/, (Erişim tarihi; 10 Eylül 2020)

Tezler

WALLS Erin, "Waves of Modern Terrorism: Examining the Past and Predicting the Future”, Georgetown Üniversitesi Yüksek Lisans tezi, Washington Nisan 2017. 